\title{
Timing of Stolon Removal Alters Daughter Plant Production and Quality in the Ever-bearing Strawberry 'Albion'
}

\begin{abstract}
Xiaonan Shi, Ricardo Hernández, and Mark Hoffmann
Department of Horticultural Science, North Carolina State University, Raleigh, NC 27695
\end{abstract}

Additional index words. precise indoor propagation, PIP, controlled environments, strawberry nurseries, strawberry stolons, strawberry tip production

\begin{abstract}
Commercial strawberry (Fragaria $\times$ ananassa Duch.) plants propagate through the development of stolons (runners) with attached daughter plants. While it is known that temperature and photoperiod affect strawberry propagation, little knowledge exists on whether cultural methods may influence stolon and daughter plant development. The objective of this study was to characterize the impact of three stolon removal treatments on the development of daughter plants in the ever-bearing strawberry 'Albion'. Treatments included 1) stolon removal every 7 days, nine times total; 2) stolon removal every 21 days, three times total; and 3) one-time stolon removal after 63 days. Strawberry plants were grown in a controlled environment $\left(26^{\circ} \mathrm{C}, 507 \mu \mathrm{mol} \cdot \mathrm{m}^{-2} \cdot \mathrm{s}^{-1}\right.$ photosynthetic photon flux density, 14-hour photoperiod) in soilless media and fertilized with a customized nutrient solution. Mother plants in the 63-day treatment produced more daughter plants (102 per plant), than in the 21-day treatment (33 per plant) and the 7-day treatment (16 per plant). In the 63-day treatment, daughter plants and stolons accumulated to $86.6 \%$ of the total biomass, to $42.9 \%$ in the 7-day treatment and to $60.6 \%$ of total biomass in the 21-day treatment. Mother plant organs (including roots, crown, and leaves) had less dry weight in the 63-day treatment compared with the 7-day treatment and 21-day treatment, respectively. Furthermore, the daughter plants produced at the 63-day treatment had smaller crown diameters $(0.65 \mathrm{~cm})$ and less dry weight $(0.51 \mathrm{~g})$ and a higher number of fully expanded leaves (2.9) and visible roots (13.4) compared with the 21-day treatment and the 7-day treatment. The results of this study show daughter plant production of strawberry plants declines significantly with shorter stolon removal intervals, indicating the need to adjust stolon removal in strawberry nurseries for optimal daughter plant production.
\end{abstract}

Cultivated strawberry plants (Fragaria $\times$ ananassa Duch.) reproduce sexually (flower/fruit) and asexually. Asexual reproduction takes place through the generation of aerial stolons (runners), which contain daughter plants on every other node. Daughter plants are new leaf rosettes with developing small roots that can develop into mature strawberry plants (Heide et al., 2013). The asexual

Received for publication 7 Dec. 2020. Accepted for publication 7 Mar. 2021

Published online 27 May 2021

This research was supported by the North Carolina Strawberry Association and the College of Agriculture and Life Sciences at NC State University. We further thank Dr. Gina Fernandez and Dr. Katie Jennings (both North Carolina State University) for providing valuable feedback on this manuscript. We also thank Cristian Collado, Emma Volk, Tekan Rana and Amanda Lay-Walters for their assistance in data assessments.

M.H. is the corresponding author. E-mail: mark. hoffmann@ncsu.edu.

This is an open access article distributed under the CC BY-NC-ND license (https://creativecommons. org/licenses/by-nc-nd/4.0/). reproduction traits of strawberries enables nurseries to propagate and sell strawberry plants on an economical scale.

Strawberry cultivars are classified as seasonal-bearing ("short-day"; SB) and everbearing ("long-day" and "day-neutral"; EB). These classifications are based on the photoperiodic flowering response under field conditions. SB cultivars initiate flowers under photoperiods lower than $12 \mathrm{~h}$ and produce stolons and daughter plants under longer photoperiods. In EB cultivars, photoperiod has a lower impact on flower initiation (Castro et al., 2015), and flower initiation can be suppressed by higher temperatures (Heide et al., 2013). EB cultivars are anecdotally known to produce lower numbers of daughter plants from each mother plant compared with SB cultivars (Bradford et al., 2010; Durner et al., 1984; Sønsteby and Heide, 2007). However, the impact of environmental factors on flowering and daughter plant production in $\mathrm{EB}$ strawberry plants is still not fully understood.

Whether an EB strawberry plant reproduces sexual or asexually relies on the differentiation of the strawberry axillary meristem
(AXM) located in the axillary bud (AXB) (Hytönen et al., 2009; Tenreira et al., 2017). Differentiation of the AXM is regulated by external and endogenous factors, such as temperature, photoperiod, nitrogen, and the hormone, gibberellin (Black, 2004; Hytönen et al., 2004; Konsin et al., 2001; Sato and Mori, 2001). Growth and dormancy of AXB are controlled by apical dominance associated with several plant hormones (Cline, 1997; Müller and Leyser, 2011). Once the terminal inflorescence is formed at the shoot apical meristem, the AXB can break dormancy. The AXM can then develop into either a branch crown (new compressed shoot section with similar behavior as primary crown, possessing the ability of producing flowers and stolons), stolon (elongated shoot with daughter plants) or an inflorescence (in cultivars with EB traits) (Guttridge, 1955).

Especially newer EB day-neutral cultivars are developed to increase strawberry production windows in the United States, with millions of transplants originating from U.S.- and Canadian-based strawberry nurseries every year. Those nurseries play a crucial role in the North American strawberry producing industry, serving a total demand of more than two billion strawberry plants (EB and SB) every year (Hoffmann, 2020). Open-field strawberry nurseries produce the bulk of the needed strawberry plants in North America and are complicated multiyear and multistate operations. The propagation process usually starts with virusfree stock plants derived from tissue culture. Cost-effective propagation in those operations often entails overall propagation rates of $1: 100,000$. Plants are multiplied in several steps in screenhouses and in propagation fields for 3 to 4 years (Hoffmann, 2020).

The productivity, cleanliness and quality of a strawberry transplant is decisive for a successful fruit production season. However, the propagation of EB cultivars leads to a multitude of problems in strawberry nurseries. Simultaneous presence of flowers and daughter plants in propagation fields increases the risk of disease contraction and induces extra labor-costs for flower removal and disease mitigation (Hoffmann, 2020). Moreover, EB cultivars usually produce fewer stolon and daughter plants than SB cultivars (Durner et al., 1984), leading to lower overall propagation numbers in strawberry nursery operations. Basic knowledge on how cultural practices in strawberry nurseries might alter propagation rates of strawberry plants are widely unknown (Hughes et al., 2017). This is especially true for the time of stolon removal. Stolon removal is performed at different time-points in a nursery operation, and can differ widely depending on production goals. No industry standards are developed as of today. Questions remain as to whether the frequency of stolon removal will have an impact on the production of daughter plants in EB strawberry cultivars. Therefore, the objective of this study was to assess the impact of different stolon removal frequencies on the daughter plant quality and propagation rates in the EB cultivar Albion, 
with the aim to develop a baseline for future strawberry propagation research. To minimize the impact of environmental factors such as photoperiod and temperature on propagation rates, the reported study was conducted in a fully controlled environment.

\section{Materials and Methods}

\section{Source of mother plants}

To avoid preexperimental floral initiation in panting material, all mother plants were grown from daughter plants that were harvested from 'Albion' stock plants growing at the North Carolina State Phytotron at a long photoperiod and consistently high temperatures $\left(16-\mathrm{h}\right.$ photoperiod, $30^{\circ} \mathrm{C}$ day $/ 25^{\circ} \mathrm{C}$ night). The stock plants were grown in $4-\mathrm{L}$ pots [1 coconut coir : 1 perlite (by volume)] and were irrigated with standard nutrient solution (N 7.6, P 0.3, K 2.8, Ca 1.4, Mg 0.5, S 0.4 in $\mathrm{mmol} / \mathrm{L}, \mathrm{Fe} 5 \mathrm{mg} / \mathrm{L}$ ) every other day.

To develop mother plants for the experiment, daughter plants with similar size crown diameter $(0.3-0.5 \mathrm{~cm})$ were harvested from the stock plants, stored at $4{ }^{\circ} \mathrm{C}$ for $24 \mathrm{~h}$, and placed into 24-cell trays (166 plants $/ \mathrm{m}^{2}$ ), filled with growing media $[1$ peatmoss : 2 pea gravel (by volume)] for rooting. Daughter plants were placed in a misting chamber with a 12-h photoperiod, $25^{\circ} \mathrm{C}$ day/night temperature for four weeks. The misting program operated during the day, with $10 \mathrm{~s}$ of misting every ten minutes during the first two weeks, six times for $30 \mathrm{~s}$ for the remainder of the propagation period. After four weeks, these new mother plants with similar crown diameter $(1.09 \pm 0.06 \mathrm{~cm})$, and leaf number $(4.6 \pm$ 0.5 ) were transplanted into $4 \mathrm{~L}$ pot $[1$ coconut coir : 1 perlite (by volume)]. The experiment started one day after transplanting.

\section{Experimental design and growing condition}

The experiment was conducted under controlled environmental conditions (14-h photoperiod, $26^{\circ} \mathrm{C}$ day/night) from 14 Aug. 2019 to 6 Nov. 2019 in a growth chamber at the North Carolina State University Phytotron $\left(18.7 \mathrm{~m}^{3}, 2.4-\mathrm{m}\right.$ width $\times 3.7-\mathrm{m}$ depth $\times 2.1$ $\mathrm{m}$ height). 'Albion' strawberry plants were grown in gutters with an automated irrigation and fertilization system. Stolon removal treatments included: 1) 7-day (stolons were removed every $7 \mathrm{~d}$; nine removal incidences), 2) 21-day (stolons were removed every $21 \mathrm{~d}$; three removal incidence), and 3) 63-day (stolons were removed once after $63 \mathrm{~d}$; one removal incidence). The experiment was conducted in a randomized complete block design with three replicates per treatment and four plants per replicate. One border plant was located between replications. Primary stolons (Fig. 1) were removed according to the treatment schedule. In the 7-day and the 21-day treatment, primary stolons were harvested from the base of the mother plant, when the oldest daughter plant on the primary stolon had at least two fully expanded leaves and visible roots (Fig. 2). Stolons from the 7-day treatment and 21-day treatment were first harvested three weeks and five weeks after the plants were placed in the growth chamber. The study was ended after $63 \mathrm{~d}$, and all stolons from the three treatments that met removal criteria were harvested.

Environmental conditions measured in the growth chamber are shown in Table 1. Temperature (Ready-Made Insulated Thermocouples with Kaptton; Omega Engineering Inc., Norwalk, CT), relative humidity (Sensirion SHT75; Sensirion, Staefa ZH, Switzerland) and carbon dioxide (Vaisala CARBOCAP; Vaisala, Helsinki, Finland) were continuously measured. Light intensity was measured by a quantum sensor meter (MQ-200; Apogee Instrument, Inc., Logan, UT) at the top of the canopy in the center of each replication. Additionally, nine fine-wire thermocouples (Type $\mathrm{T}$, gauge 24; Omega Inc., Stamford, CT) were positioned above the canopy (one per replicate) to measure the canopy temperature. Environmental data were recorded every five minutes using a data logger (CR1000; Campbell Scientific, Logan, UT) (Table 1). Three soil moisture sensors (ECH2O EC-5; METER Environment, Pullman, WA) were inserted into three pots of three treatments to monitor the water content of the substrate. The irrigation system was controlled by substrate moisture levels. A customized nutrient solution $(\mathrm{N}$ 7.1, P 0.7, K 3.7, Ca 1.5, Mg 0.5, S 1.2, Mn $0.03, \mathrm{Zn} \mathrm{0.004,} \mathrm{Cu} \mathrm{0.001,} \mathrm{B} 0.06$ in mmol/L, $\mathrm{Fe} 2.5 \mathrm{mg} / \mathrm{L}$ ) was applied to all the strawberry plants in the growth chamber through automatic drip irrigation controlled by the soil moisture sensors. One ring irrigation pipe was placed on the surface of the substrate in each pot. One emitter $(8 \mathrm{~L} / \mathrm{h})$ was connected to one ring irrigation pipe. The triggering threshold of water content of substrate was set to $35 \%$. Electrical conductivity (EC) and $\mathrm{pH}$ were measured by a $\mathrm{pH} / \mathrm{EC}$ meter (AI423 PC400S Portable Multi-Parameter Meter Kit; Apera Instruments, LLC, Columbus, $\mathrm{OH}$ ) every other day. The percentage of drainage were calculated every other day via collecting the input volume of one pot/emitter and the out volume of drain of whole gutter (16 pots in total). The average $\mathrm{pH}$ of feed and drain solution was 6.08 and 5.23, respectively. The average EC of feed and drain solution was 0.95 and $1.17 \mathrm{mS} / \mathrm{cm}$, respectively. The drainage was kept at $13.7 \%$ throughout the experiment. The nutrient solution was sampled once a month to be sent to Agronomic Services at NCDA (North Carolina Department of Agriculture \& Consumer Services, Raleigh, NC) for nutrient composition tests.

\section{Plant traits and data analysis}

Daughter plant assessment. The number of daughter plants with visible roots were counted weekly in all treatments, before stolon removal. After stolon removal, crown diameter was measured at the widest part of the crown using a caliper on a ruler scale. Fresh weight of each daughter plant was measured using an electronic scale (Mettler PE 1600; Mettler-Toledo International Inc., Columbus,

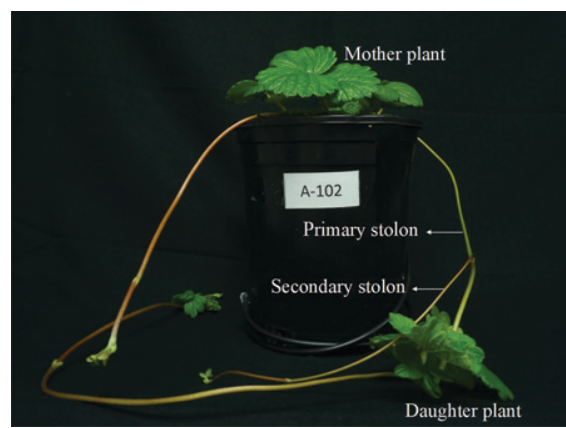

Fig. 1. A mother plant 'Albion' with two primary stolons and a daughter plant. The primary stolon that has a daughter plant generated a secondary stolon at the first node of primary stolon.

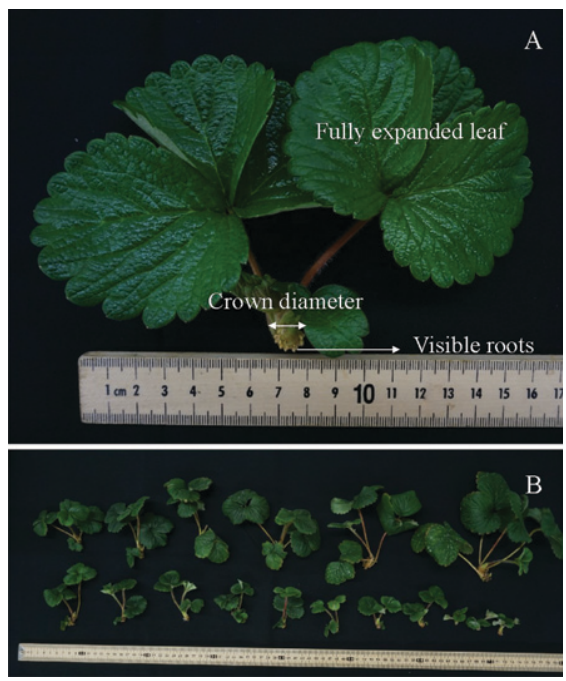

Fig. 2. Daughter plant 'Albion' morphology (A) and picture of all daughter plants harvested from one stolon of 63-day treatment (B). In A, a daughter plant harvested from the 7-day treatment. In $\mathbf{B}$, daughter plants harvested in the 63-day treatment (oldest to youngest daughter plant: from the top right to the right on the bottom row). "7-day treatment" is that stolon removal/daughter plant harvest occurred at 7-d interval; "63-day treatment" is that stolon removal/daughter plant harvest occurred at 63-d interval.

$\mathrm{OH})$. Afterward, daughter plants were dried for $48 \mathrm{~h}$ (31-350 Analog Bench Oven; Quincy Laboratory, Chicago, IL) at $80^{\circ} \mathrm{C}$ and dry weights were recorded (Mettler PE 1600, Mettler-Toledo International Inc.).

To describe daughter plant quality traits (Fig. 2A), daughter plants from all treatments were categorized based on crown diameter (C), number of fully expanded leaves (L), number of visible roots (R), and dry weight (D). The distribution of each plant trait was categorized in the lower $25 \%$ (1), the middle $50 \%(\mathrm{~m})$, and the higher $25 \%(\mathrm{~h})$ percentile for each treatment (Table 2). The capital letter of the plant trait and lowercase letter of the range were combined as a trait-class: $\mathrm{Cl}$, $\mathrm{Cm}$, and $\mathrm{Ch}$ (crown diameter; lower, middle, higher percentile); Ll, Lm, and $\mathrm{Lh}$ (number of fully expanded leaves; lower, middle, higher percentile); Rl, Rm, and Rh (number 
Table 1. Environmental conditions (light source, light intensity, photoperiod, temperature, relative humidity, water content of substrate) inside the growth chamber (mean $\pm \mathrm{sD}, \mathrm{n}=3$ ).

\begin{tabular}{|c|c|c|c|c|c|}
\hline Stolon removal treatment ${ }^{z}$ & Light source & PPFD $\left(\mu \mathrm{mol} \cdot \mathrm{m}^{-2} \cdot \mathrm{s}^{-1}\right)$ & Photoperiod (h) & Temperature $\left({ }^{\circ} \mathrm{C}\right)$ & Relative humidity (\%) \\
\hline 7-day treatment & Fluorescent $(5000$ and $6500 \mathrm{~K}$ & $508 \pm 9$ & & $26.1 \pm 0.2$ & \\
\hline $\begin{array}{l}\text { 21-day treatment } \\
63 \text {-day treatment }\end{array}$ & color temp) & $\begin{array}{l}506 \pm 12 \\
506 \pm 15\end{array}$ & 14 & $\begin{array}{l}25.9 \pm 0.3 \\
26.2 \pm 0.4\end{array}$ & $73 \pm 3.3$ \\
\hline
\end{tabular}

"7-day treatment" is that stolon removal/daughter plant harvest occurred at 7-d interval; "21-day treatment" is that stolon removal/daughter plant harvest occurred at 21-d interval; "63-day treatment" is that stolon removal/daughter plant harvest occurred at 63-d interval.

$P P F D=$ photosynthetic photon flux density.

Table 2. Classes of four plant traits (crown diameter, number of leaves, number of roots, and dry weight) of daughter plant quality. Each trait range is split into three groups based on the lower quartile and upper quartile. The three groups of data range are lower $25 \%$, middle $50 \%$, and higher $25 \%$. Trait-classes are abbreviated to a combination of capital letter of each plant trait and lowercase letter of range group.

\begin{tabular}{|c|c|c|c|c|c|c|c|c|}
\hline \multirow[b]{2}{*}{ Groups of range } & \multicolumn{2}{|c|}{ Crown diam $(\mathrm{cm})$} & \multicolumn{2}{|c|}{ No. of leaves } & \multicolumn{2}{|c|}{ No. of roots } & \multicolumn{2}{|c|}{ Dry wt (g) } \\
\hline & Class & Range & Class & Range & Class & Range & Class & Range \\
\hline Lower $25 \%$ & $\mathrm{Cl}^{\mathrm{Z}}$ & $\begin{array}{c}\leq 0.6 \\
0.6<\mathrm{Cm}\end{array}$ & $\mathrm{Ll}$ & 1 & $\mathrm{Rl}$ & $\begin{array}{c}\quad \leq 4 \\
4<\mathrm{Rm}\end{array}$ & $\overline{\mathrm{D} 1}$ & $\begin{array}{c}\leq 0.2 \\
>0.2<\mathrm{Dm}\end{array}$ \\
\hline Middle $50 \%$ & $\mathrm{Cm}$ & $\leq 0.8$ & $\mathrm{Lm}$ & 2 or 3 & $\mathrm{Rm}$ & $\leq 17$ & Dm & $\leq 0.7$ \\
\hline Higher $25 \%$ & $\mathrm{Ch}$ & $>0.8$ & $\mathrm{Lh}$ & $\geq 4$ & $\mathrm{Rh}$ & $>17$ & Dh & $>0.7$ \\
\hline
\end{tabular}

${ }^{\mathrm{z}} \mathrm{Cl}$ represents the group of daughter plants with crown diameter smaller than $0.6 \mathrm{~cm}$ (the lower $25 \%$ of entire population).

of visible roots; lower, middle, higher percentile); and Dl, Dm, and Dh (dry weight; lower, middle, higher percentile). Each daughter plant was assigned with four trait-classes. The percentage of each category was calculated for the population of daughter plants of a specific treatment.

Stolon assessment. The primary stolon is the stolon directly attached to the mother plant. The stolon emerging from the AXB either at the first node of sympodial unit of the primary stolon or of a daughter plant is called secondary stolon (Fig. 1). The number of primary and secondary stolons were counted weekly. The length of first and second internodes of every stolon was assessed after removal. Afterwards, the stolon was cut at every first node and the base of the daughter plants, and fresh and dry weight was measured for the first and second internode separately, following the procedure described above.

Mother plant assessment. At final stolon removal, two strawberry mother plants were randomly selected from each replication of each treatment (18 plants in total). The remaining stolons and dead leaves were removed, and the number of leaves and the crown diameter were assessed. Afterward the substrate was gently washed off each mother plant. Mother plants were then divided into three parts: leaves, crown, and root, dried at $70{ }^{\circ} \mathrm{C}$ for at least $72 \mathrm{~h}$, and dry weight was measured (Mettler Toledo PL1502E, MettlerToledo International Inc.).

Data analysis. The effect of stolon removal treatments was analyzed using a one-way ANOVA (PROC GLM, SAS software; SAS Institute Inc., Cary, NC) and mean separation by Fisher's protected least significant difference (LSD) test $(\alpha=0.05)$. The cumulative number of daughter plants and stolons was calculated weekly. Cumulative number vs. weekly counts were fitted with a linear regression model by procedure PROC REG in
SAS. The statistical comparison was conducted on the percentage and the amount of daughter plants within one category between three removal treatments. The comparison was completed by procedure PROC GLM procedure of SAS software (SAS Institute Inc.) and mean separation by Fisher's protected LSD test $(\alpha=0.05)$.

\section{Results}

\section{Daughter plant production}

Total and weekly production of daughter plants. The average number of daughter plants per mother plant in the 63-day treatment was $102 \pm 4.5$ in the 63-day treatment, $33 \pm 1.9$ in the 21-day treatment, and $16 \pm 1.0$ in the 7day treatment (Fig. 3A). Cumulative weekly production of daughter plants increased linearly during the first 12 weeks in the 7-day and 21-day treatments and increased exponentially in the 63-day treatment (Fig. 3B).

Total production of stolons. No difference of the cumulative number of primary stolons was observed between 7-day treatment (12.2) and 21-day treatment (13.1). In the 63-day treatment, the number of cumulative primary stolons was lower (9) than in the other two treatments (Fig. 4A). In the 7-day treatment and the 21-day treatment, the cumulative production of primary stolons followed a linear pattern (Fig. 4B), while the number of primary stolons produced in the 63-day treatment followed a logarithmic regression curve (Fig. 4B). However, less frequent stolon removal increases daughter plant production. The average number of secondary stolons of each mother plant was 1.1 in the 7-day treatment, 7 in the 21-day treatment, and 22.2 in the 63day-treatment (Fig. 4A).

Daughter plant quality. The crown diameter of the daughter plant was decreasing as increasing the frequency of stolon removal. The same trend was observed in the dry weight of daughter plant (Table 3). The number of fully expanded leaves and the number of visible roots were both increasing as increasing the frequency of stolon removal (Table 3). Higher percentage of daughter plants of the class $\mathrm{Ch}$ (crown diameter $>0.8 \mathrm{~cm}$ ) were found in the 7-day treatment $(54 \%)$, compared with the 63-day treatment $(14.8 \%)$, while the percentage of daughter plants with more than three expanded leaves (Lh) and more than 17 visible roots ( $\mathrm{Rh}$ ) was increasing, respectively, with lower frequency of stolon removal (Table 4). Only $18.9 \%$ of daughter plants in the 63-day treatment had fewer than four visible roots $(\mathrm{Rl})$, while $41.6 \%$ of daughter plants in the 7-day treatment and $40.1 \%$ of that in the 21-day treatment had fewer than four visible roots (Table 4).

Mother plants. All strawberry mother plants maintained vegetative growth and no flowering was observed at any time throughout the experiment. No differences were observed for leaf number, crown diameter, and total dry weight of leaves, crown, and total plant between the 7-day treatment and the 21-day treatment. However, the mother plants in the 63day treatment had the lowest dry weight for leaf, crown and root, but the highest dry weight of stolons and daughter plants (Table 5).

\section{Discussion}

Less frequent stolon removal increases daughter plant production. Harvesting stolons after $63 \mathrm{~d}$ significantly increased the amount of daughter plants produced in the EB strawberry cultivar Albion, compared with the shorter harvest treatments. The production of stolons relies on the differentiation of two types of AXM: 1) the AXM of the primary crown that regulates flowering vs. primary stolon production (Savini et al., 2008; Sugiyama et al., 2004), and 2) the AXM of primary stolon that either grows secondary stolons or remains dormant (Hytönen et al., 2009). The significant increase of daughter plants in the 63-day treatment could be directly explained through differences in the length of the primary stolon and the number of secondary stolons between treatments. Although a reduced number of primary stolons was observed in 63-day treatment, each stolon produced more daughter plants due to longer growth period, compared with the 21-day treatment and the 7-day treatment. This observation is consistent with the results of study of Hughes et al. (2017), who investigated the effects of stolon removal on plant growth of two EB strawberry cultivars (Albion and Seascape) at two sites in Canada. Hughes et al. (2017) implemented 

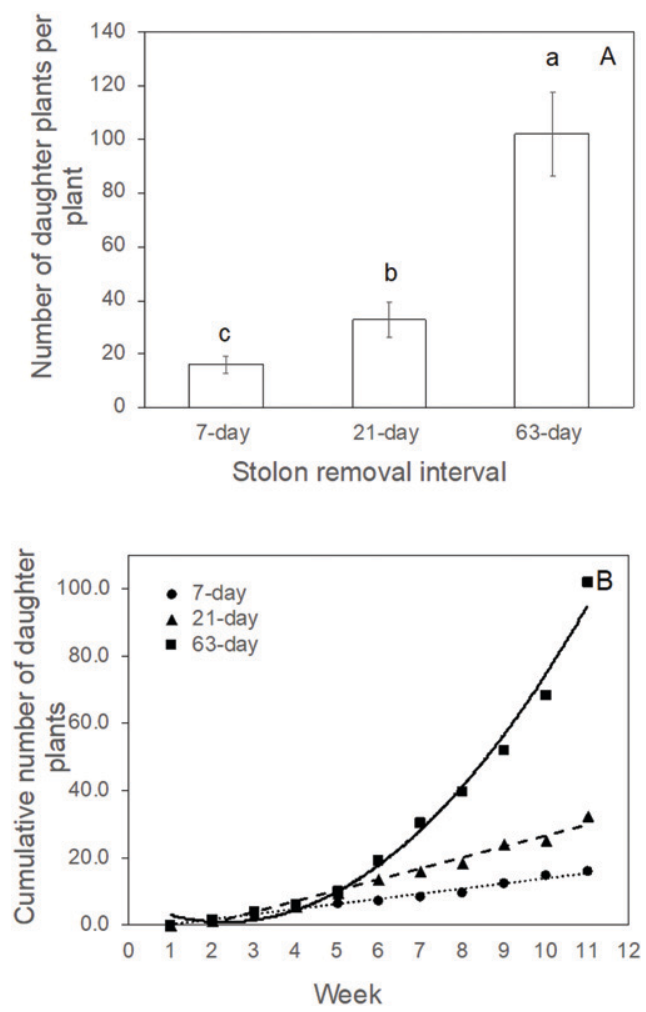

Fig. 3. (A) Total number of daughter plants per mother plant 'Albion' in 7-day, 21-day, and 63-day treatments (mean $\pm \mathrm{SD}, \mathrm{n}=12$ ). Letters indicate significant differences tested by Fisher's protected least significant difference $(\alpha=0.05)$. (B) Cumulatively weekly production rate of daughter plants per mother plant 'Albion'. Black dots and dotted line: 7-day treatment data, DP $=-1.13+1.51$ Week $\left(R^{2}=0.980\right)$. Triangles and dash line: 21 -day treatment data, $\mathrm{DP}=-5.12+3.09$ Week $\left(R^{2}=0.989\right)$. Squares and solid line: 63-day treatment data, $\mathrm{DP}=1.94-2.28 \mathrm{Week}+0.87 \mathrm{Week}^{2}\left(R^{2}=0.998\right)$. "7-day" is that stolon removal/daughter plant harvest occurred at 7-d interval; "21-day" is that stolon removal/daughter plant harvest occurred at 21-d interval; "63-day" is that stolon removal/daughter plant harvest occurred at 63-d interval.

four treatments in their study: weekly, three times, one time, and never. The results showed that, by reducing the incidents of stolon removal during the trial at both sites, the number of stolons generated were reduced, but the total dry weight of removed plant materials (including the stolons and daughter plants) was increased.

We also observed that the number of secondary stolons significantly increased in the 63-day treatment, compared with the 21-day treatment and 7-day treatment. The majority of daughter plants were produced on secondary stolons in the 63-day treatment. The study of Hytönen et al. (2009) showed AXM differentiation to new stolons under favorable environmental conditions. In Hytönen et al. (2009), the SB strawberry cultivar Korona was growing continuous sympodial units under long-day photoperiods ( $18 \mathrm{~h}$ ) but stopped after being exposed to short-day photoperiod $(10,12$, and 14 h). They hypothesized that strawberry plants could continuously grow daughter plants as long as the plants are under favorable conditions for asexual propagation. Therefore, the strawberry plants grown in our experiment have been exposed to conditions in favor of breaking dormancy of AXM on primary stolons (at $26^{\circ} \mathrm{C}$, under $14-\mathrm{h}$ photoperiod). Plants in the 63-day treatment were able to exhibit a greater number of sympodial units with daughter plants per primary stolon, compared with the 7-day treatment and the 21-day treatment.

The dry weight of leaves, crown, and roots of the mother plant was less in the 63day treatment, compared with the other two treatments. The variation of dry weight reflects on assimilate allocation via sink-source relationships in a plant (Dingkuhn et al., 2007; Patrick and Colyvas, 2014; Paul and Foyer, 2001). The assimilate production rate indicates the source strength of a plant organ, usually measured through photosynthesis ( $\mathrm{Li}$ et al., 2015). The assimilate allocation is driven by sink strength that is defined as each plant organ's capability of competing for assimilates (Marcelis, 1996). While photosynthetic rates were not measured in our study, dry weight relationships between mother plant organs, stolons and daughter plant may be due to source-sink relationships between the different treatments in our study. In strawberry plants without flower or fruit present, the assimilate source are the matured leaves, and the total sink strength is composed by roots, crowns, young leaves, stolons and daughter plants (Blanke and Cooke, 2000; Garcia and Kubota, 2017). Turgeon (1989) demonstrated that leaves of dicotyledons stop importing and begin exporting assimilates when they are $30 \%$ to $60 \%$ fully expanded.
On this basis, the dry weight and number of leaves can be used as an indicator for the source strength of a mother plant in our experiment. Observed differences in dry weight between treatments could be a result of differences in sink strength of stolons and daughter plants. With no flower and fruit, the distribution of photosynthates might be driven by the development of stolons and daughter plants that have potentially higher sink strength than other mother plant organs (Muola and Stenberg, 2018). In the 7-day treatment and 21-day treatment, stolons were frequently removed from mother plants and therefore could have reduced the sink strength of stolons and daughter plants. The plant would allocate more assimilate to crowns and roots, due to the presence of fewer stolons and daughter plants per mother plant, compared with the 63-day treatment. Similar dry weight partitioning was observed in strawberry (Menzel and Smith, 2014) as well as in tomato plants ( $\mathrm{Li}$ et al., 2015). In the study of Menzel and Smith (2014), the seasonal changes in the distribution of dry weight of strawberry cultivar Festival was observed over a time period of 2 years. The results showed that the dry weight portioning to leaves, crowns, and roots dropped, and there was a rise in the distribution to reproductive tissues, as the strongest sink, when the fruiting season progressed in the strawberry field (Menzel and Smith, 2014). In the study of Li et al. (2015), two fruit loads (standard and half) were implemented on three cultivars of tomato plants. The dry weight partitioning to leaves and stems significantly increased when the fruit load was cut off half in all three cultivars of tomato plants. The research of Li et al. (2015) also calculated the sink strength throughout the whole planting season and found that the total sink strength started to rise after the fruit started to set.

It is rather unlikely that assimilates provided by the mother plant alone led to the exponential increase of daughter plants in the 63-day treatment. Lower leaf dry weight in the mother plant would have provided less assimilates in the 63-day treatment. The dry weight of mother plant leaves was almost three times less in the 63-day treatment, compared with the 7-day treatment (5.82 $\mathrm{g}$ of 63 day treatment and $16.17 \mathrm{~g}$ of 7-day treatment). However, mother plants of the 63-day treatment produced six times more daughter plants (102 per plant) and five times more overall dry weight of daughter plants (53.19 g) than plants of the 7-day treatment, and three times more daughter plants as well as overall dry weight than plants in the 21-day treatment. Our data suggest that older daughter plants might be involved in supporting their own growth, and possibly contribute to the distribution of photoassimilates along a stolon toward younger sink tissue (developing stolon and daughter plants). This process is called "clonal integration," defined as the share of assimilates and other resources between strawberry plants connected through a stolon (Alpert, 1991, 1999; Narváez-Ortiz et al., 2018; Roiloa 

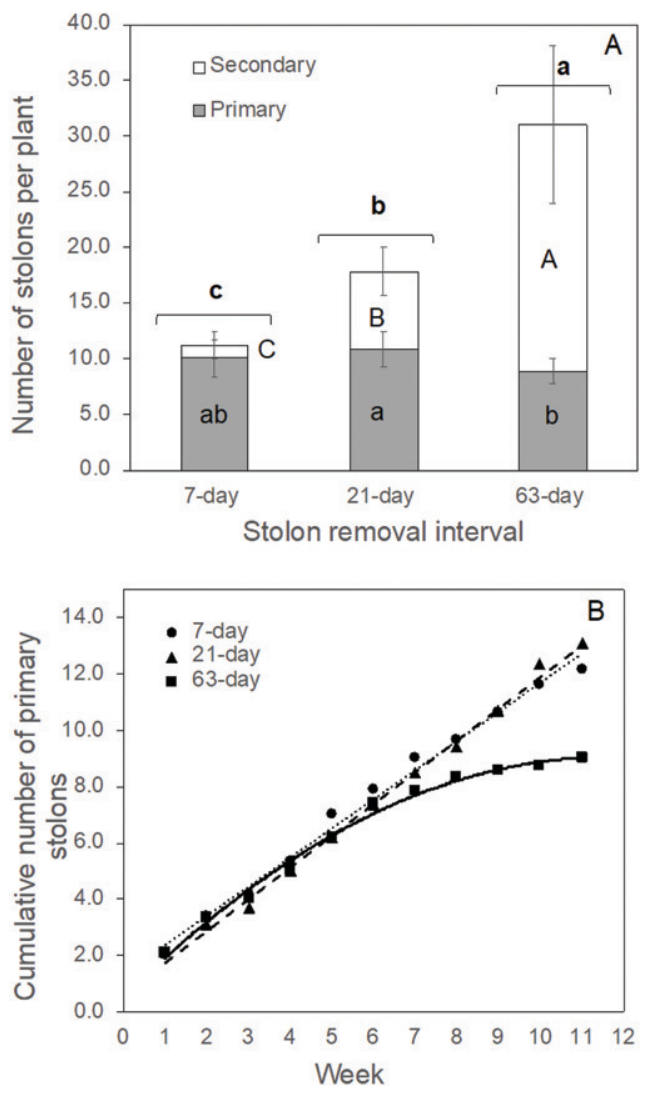

Fig. 4. (A) Average number of primary and secondary stolons harvested at 7-day, 21-day, and 63-day treatments from mother plants 'Albion' (mean $\pm \mathrm{SD}, \mathrm{n}=12$ ). Shaded bar represents the number of primary stolons and blank bar represents the number of secondary stolons. Capital letters and lowercase letters indicate significance levels of primary stolon and secondary stolon respectively, and bolded lowercase letters indicate significance levels of total stolons [Fisher's protected least significant difference $(\alpha=0.05)]$. (B) Cumulatively weekly production rate of primary stolon (pST) from mother plants 'Albion' in three treatments. Squares on dotted line: 7-day treatment, pST $=1.35+$ 1.03 Week $\left(R^{2}=0.991\right)$; Triangles and dash line: 21 -day treatment, $\mathrm{pST}=0.64+1.13 \mathrm{Week}\left(R^{2}=\right.$ 0.996); Squares on solid line: 63-day treatment, pST $=0.51+1.46 \mathrm{Week}-0.06 \mathrm{Week}^{2}\left(R^{2}=\right.$ $0.992)$. "7-day" is that stolon removal/daughter plant harvest occurred at 7-d interval; "21-day" is that stolon removal/daughter plant harvest occurred at 21-d interval; "63-day" is that stolon remov$\mathrm{al} /$ daughter plant harvest occurred at 63-d interval.

Table 3. The mean \pm SD of four plant traits (crown diameter, number of fully expanded leaves, number of roots, and dry weight) of daughter plants 'Albion'.

\begin{tabular}{lcccc}
\hline & & No. of fully & No. of visible \\
Treatment & Crown diam $(\mathrm{cm})$ & $\begin{array}{c}\mathrm{y} \\
\text { expanded leaves }\end{array}$ & roots & Dry wt $(\mathrm{g})$ \\
\hline 7-day treatment & $0.89 \pm 0.08 \mathrm{a}$ & $2.1 \pm 0.0 \mathrm{c}$ & $6.3 \pm 0.9 \mathrm{~b}$ & $0.62 \pm 0.02 \mathrm{a}$ \\
21-day treatment & $0.77 \pm 0.06 \mathrm{~b}$ & $2.3 \pm 0.1 \mathrm{~b}$ & $8.2 \pm 0.5 \mathrm{~b}$ & $0.57 \pm 0.03 \mathrm{~b}$ \\
63-day treatment & $0.65 \pm 0.02 \mathrm{c}$ & $2.9 \pm 0.1 \mathrm{a}$ & $13.4 \pm 1.1 \mathrm{a}$ & $0.51 \pm 0.03 \mathrm{c}$ \\
$P$ value & $<0.001$ & $<0.001$ & $<0.001$ & $<0.001$ \\
\hline
\end{tabular}

${ }^{\mathrm{z}}$ Letters $(\mathrm{a}, \mathrm{b}, \mathrm{c})$ following the numbers indicate significance levels tested by Fisher's protected least significant difference $(\alpha=0.05)$.

${ }^{\mathrm{y}} 7$-day treatment" is that stolon removal/daughter plant harvest occurred at 7-d interval; "21-day treatment" is that stolon removal/daughter plant harvest occurred at 21-d interval; "63-day treatment" is that stolon removal/daughter plant harvest occurred at 63-d interval. and Retuerto, 2006; Savini et al., 2008). Older daughter plants in our study might have contributed to the development of new daughter plants through clonal integration, resulting in the highest number of daughter plants in the 63-day treatment.

Quality characteristics of daughter plant vary among three removal treatments. Plant growth and development during strawberry transplant establishment relies among other factors on the quality of a daughter plant. Durner et al. (2002) suggested that crown diameter of daughter plants should be between $2-5 \mathrm{~mm}$ for subsequent high vigor of transplants. Xu and Hérnandez (2020) used crown diameter to classify 'Albion' daughter plants produced under different light intensities. While crown diameter is commonly used as an indicator for vigor and quality of bare-root transplants in the United States (Cocco et al., 2011; Lieten, 2014) and European transplant grading systems (Lieten, 2014), the use of crown diameter as quality indicator for daughter plants is anecdotal (Durner et al., 2002). The quality of a daughter plant does differ from quality characteristics used for transplants for fruiting fields, and would be determined rather based on their capacity to root and develop a healthy canopy. To gather a more comprehensive overview on daughter plant development, we chose to characterize four traits for each harvested daughter plant in our experiment: crown diameter, number of leaves, number of roots, dry weight. We found that daughter plants of the 7-day treatment had a larger crown diameter and dry weight, and a lower number of leaves and roots. Daughter plants of the 63-day treatment showed smaller crown diameters and lower dry weight, but a higher number of leaves and roots than all other treatments. A correlation between the descriptive traits used in our study, and daughter plant performance, such as rooting time and growth rate during early establishment as transplant, inflorescent production and fruit yield later in the field, remains to be investigated. Research has shown that older roots of transplants are inactive for water and nutrient uptake, leading to low survival rate after planting into a fruiting field (Nicola, 1998). Moreover, Takeda et al. (2004) found that daughter plants with a fresh weight $<0.9 \mathrm{~g}$ were less suited for plug plant production, compared with daughter plants with fresh weight $>0.9 \mathrm{~g}$.

Defining reliable traits for daughter plant quality assessments is important to develop

Table 4. The percentage of daughter plant 'Albion' in the classes (lower 25\%, middle 50\%, and higher 25\%) of four quality plant traits (crown diameter, number of fully expanded leaves, number of visible roots, and dry weight. ${ }^{\mathrm{z}}$

\begin{tabular}{|c|c|c|c|c|c|c|c|c|c|c|c|c|}
\hline Treatment $^{\mathrm{y}}$ & \multicolumn{3}{|c|}{ Crown diam } & \multicolumn{3}{|c|}{ No. of fully expanded leaves } & \multicolumn{3}{|c|}{ No. of visible roots } & \multicolumn{3}{|c|}{ Dry wt } \\
\hline 7-day treatment & $15.8 \mathrm{~b}$ & $30.0 \mathrm{a}$ & $54.2 \mathrm{a}$ & $11.0 \mathrm{a}$ & $87.4 \mathrm{a}$ & $1.60 \mathrm{c}$ & $41.6 \mathrm{a}$ & $56.8 \mathrm{a}$ & $1.60 \mathrm{c}$ & $14.7 \mathrm{~b}$ & $49.0 \mathrm{ab}$ & $36.3 \mathrm{a}$ \\
\hline 21-day treatment & $27.7 \mathrm{ab}$ & $30.7 \mathrm{a}$ & $41.6 \mathrm{a}$ & $19.5 \mathrm{a}$ & $67.8 \mathrm{~b}$ & $12.7 \mathrm{~b}$ & $40.1 \mathrm{a}$ & $49.0 \mathrm{a}$ & $10.9 \mathrm{~b}$ & $26.4 \mathrm{a}$ & $43.7 \mathrm{~b}$ & $29.9 \mathrm{a}$ \\
\hline$P$ value & 0.035 & 0.105 & 0.004 & 0.127 & 0.001 & $<0.001$ & 0.024 & 0.475 & $<0.001$ & 0.049 & 0.047 & 0.017 \\
\hline
\end{tabular}

${ }_{\mathrm{z}}$ Letters $(\mathrm{a}, \mathrm{b}, \mathrm{c})$ following the numbers indicate significance levels [Fisher's protected least significant difference $(\alpha=0.05)$ ].

${ }^{\mathrm{y}}$ 7-day treatment" is that stolon removal/daughter plant harvest occurred at 7-d interval; "21-day treatment" is that stolon removal/daughter plant harvest occurred at 21-d interval; "63-day treatment" is that stolon removal/daughter plant harvest occurred at 63-d interval.

${ }^{\mathrm{x}} \mathrm{Cl}$ represents the group of daughter plants with crown diameter smaller than $0.6 \mathrm{~cm}$ (the lower $25 \%$ of entire population of each treatment). 
Table 5. Dry weight (g; \%) of each organ of mother plants, the leaf number and the crown diameter of mother plants 'Albion' $(\mathrm{n}=6$ per treatment). Shown are mean $\pm \mathrm{SD}^{\mathrm{z}}$

Dry wt (g)

\begin{tabular}{|c|c|c|c|c|c|c|c|c|}
\hline Treatment $^{\mathrm{y}}$ & Stolon & Daughter plant & Leaf & Crown & Root & Whole plant & Leaf number & Crown diam $(\mathrm{cm})$ \\
\hline 7-day treatment & $11.69 \pm 1.18 \mathrm{c}$ & $10.45 \pm 0.88 \mathrm{c}$ & $16.17 \pm 0.66 \mathrm{a}$ & $1.51 \pm 0.06 \mathrm{a}$ & $11.65 \pm 1.84 \mathrm{a}$ & $51.46 \pm 3.59 b$ & $14.00 \pm 0.86 \mathrm{a}$ & $1.82 \pm 0.03 \mathrm{a}$ \\
\hline 21-day treatment & $17.60 \pm 1.12 b$ & $19.41 \pm 1.52 \mathrm{~b}$ & $15.10 \pm 0.29 \mathrm{a}$ & $1.48 \pm 0.06 \mathrm{a}$ & $7.20 \pm 0.38 b$ & $60.78 \pm 2.41 \mathrm{~b}$ & $15.83 \pm 0.48 \mathrm{a}$ & $1.74 \pm 0.06 \mathrm{a}$ \\
\hline $\begin{array}{l}63 \text {-day treatment } \\
P \text { values }\end{array}$ & $\begin{array}{c}28.82 \pm 1.84 \mathrm{a} \\
<0.001\end{array}$ & $\begin{array}{c}53.19 \pm 3.11 \mathrm{a} \\
<0.001\end{array}$ & $\begin{array}{l}5.82 \pm 0.32 b \\
\quad<0.001\end{array}$ & $\begin{array}{c}0.89 \pm 0.05 \mathrm{~b} \\
<0.001\end{array}$ & $\begin{array}{c}5.50 \pm 0.62 \mathrm{~b} \\
0.008\end{array}$ & $\begin{array}{c}94.23 \pm 4.78 \mathrm{a} \\
<0.001\end{array}$ & $\begin{array}{l}9.83 \pm 0.70 \mathrm{~b} \\
<0.001\end{array}$ & $\begin{array}{c}1.35 \pm 0.05 \mathrm{~b} \\
<0.001\end{array}$ \\
\hline
\end{tabular}

${ }_{\mathrm{z}}$ Letters $(\mathrm{a}, \mathrm{b}, \mathrm{c})$ indicate significance levels [Fisher's protected least significant difference $(\alpha=0.05)$ ].

${ }^{\mathrm{y}} 7$-day treatment" is that stolon removal/daughter plant harvest occurred at 7-d interval; "21-day treatment" is that stolon removal/daughter plant harvest occurred at 21-d interval; "63-day treatment" is that stolon removal/daughter plant harvest occurred at 63-d interval.

quality standards and optimal nursery production strategies. While longer growth periods of stolons in open-field strawberry nurseries could result in exponential more daughter plants, it is not clear whether daughter plant quality remains the same under less frequent stolon removal regimes. Moreover, commercial field-based nursery operations might see major concerns in adapting less frequent removal periods, due to the potential of increased disease contraction in the field.

\section{Conclusion}

Less frequent stolon removal increased the rate of strawberry daughter plant production per mother plant and reduced the number of stolons in the EB strawberry cultivar Albion. Stolon removal treatments impact morphological and physiological characteristics of daughter plants, and longer removal treatments showed increased dry weight of stolons and daughter plants. Our findings provide important baseline information for strawberry nursery operators who seek to increase daughter plant production rates. Strategies of prolonged daughter plant harvest intervals could be implemented in future protected and open-field nursery operations. However, the relationships between daughter plant quality and rooting behavior and growth rates of transplants need to be further investigated.

\section{Literature Cited}

Alpert, P. 1991. Nitrogen sharing among ramets increases clonal growth in Fragaria chiloensis. Ecology 72:69-80, doi: 10.2307/1938903.

Alpert, P. 1999. Clonal integration in Fragaria chiloensis differs among populations: Ramets from grassland are selfish. Oecologia 120:69-76, doi: 10.1007/s004420050834.

Black, B.L. 2004. Prohexadione-calcium decreases fall runners and advances branch crowns of 'Chandler' strawberry in a cold-climate annual production system. J. Amer. Soc. Hort. Sci. 129:479-485, doi: 10.21273/JASHS.129.4.0479.

Blanke, M.M. and D.T. Cooke. 2000. Respiration and plasma membrane ATPase in strawberry stolons. Plant Growth Regulat. 30:163-170, doi: 10.1023/A:1006314629955.

Bradford, E., J.F. Hancock, and R.M. Warner. 2010. Interactions of temperature and photoperiod determine expression of repeat flowering in strawberry. J. Amer. Soc. Hort. Sci. 135:102-107, doi: 10.21273/JASHS.135.2.102.

Castro, P., J.M. Bushakra, P. Stewart, C.K. Weebadde, D. Wang, J.F. Hancock, C.E. Finn, J.J. Luby, and K.S. Lewers. 2015. Genetic mapping of day- neutrality in cultivated strawberry. Mol. Breed. 35:79-94, doi: 10.1007/s11032-015-0250-4.

Cline, M.G. 1997. Concepts and terminology of apical dominance. Amer. J. Bot. 84:1064-1069.

Cocco, C., J.L. Andriolo, F.L. Cardoso, L. Erpen, and O.J. Schmitt. 2011. Crown size and transplant type on the strawberry yield. Scientia Agricola 68:489-493, doi: 10.1590/S010390162011000400015

Dingkuhn, M., D. Luque, A. Clément-Vidal, L. Tambour, H.K. Kim, and Y.H. Song. 2007. Is plant growth driven by sink regulation? Implications for crop models, phenotyping approaches and ideotypes. Frontis 21:155-168.

Durner, E.F., E.B. Poling, and J.L. Mass. 2002. Recent advances in strawberry plug transplant technology. HortTechnology 12:545-550, doi: 10 . 21273/HORTTECH.12.4.545.

Durner, E.F., J.A. Barden, D.G. Himelrick, and E.B Poling. 1984. Photoperiod and temperature effects on flower and runner development in dayneutral, June-bearing and ever-bearing strawberries. J. Amer. Soc. Hort. Sci. 109:396-400.

Garcia, K. and C. Kubota. 2017. Physiology of strawberry plants under controlled environment: Diurnal change in leaf net photosynthetic rate. Acta Hort. 1156:445-452, doi: 10.17660/ ActaHortic.2017.1156.66.

Guttridge, C.G. 1955. Observations on the shoot growth of the cultivated strawberry plant. J. Hort. Sci. 30:1-11, doi: 10.1080/00221589.1955.115 13823.

Heide, O.M., J.A. Stavang, and A. Sønsteby. 2013. Physiology and genetics of flowering in cultivated and wild strawberries - a review. J. Hort Sci. Biotechnol. 88:1-18, doi: 10.1080/14620 316.2013.11512930.

Hoffmann, M. 2020. An overview of the strawberry nursery industry in North America. Oral presentation, American Society of Horticultural Science Annual Virtual Meeting, 10-13 Aug. 2020. <https://ashs.confex.com/ashs/2020/ meetingapp.cgi/Paper/33736 $>$ (abstr.).

Hytönen, T., P. Palonen, K. Mouhu, and O. Junttila. 2004. Crown branching and cropping potential in strawberry (Fragaria $\times$ ananassa Duch.) can be enhanced by daylength treatments. J. Hort. Sci. Biotechnol. 79:466-471, doi: 10.1080/14620316. 2004.11511791.

Hytönen, T., P. Elomaa, T. Moritz, and O. Junttila. 2009. Gibberellin mediates daylength- controlled differentiation of vegetative meristems in strawberry (Fragaria $\times$ ananassa Duch). BMC Plant Biol. 9, doi: 10.1186/1471-2229-9-18.

Hughes, B.R., J. Zandstra, T. Taghavi, and A. Dale. 2017. Effects of runner removal on productivity and plant growth of two day-neutral strawberry cultivars in Ontario, Canada. Acta Hort. 1156:327-332, doi: 10.17660/ActaHortic. 2017.1156.50

Konsin, M., I. Voipio, and P. Palonen. 2001. Influence of photoperiod and duration of short-day treatment on vegetative growth and flowering of strawberry (Fragaria $\times$ ananassa Duch.). J. Hort. Sci. Biotechnol. 76:77-82, doi: 10.1080 14620316.2001.11511330.

Li, T., E. Heuvelink, and F.M. Marcelis. 2015. Quantifying the source-sink balance and carbohydrate content in three tomato cultivars. Front. Plant Sci. 6, doi: 10.3389/fpls.2015.00416.

Lieten, P. 2014. The strawberry nursery industry in the Netherlands: An update. Acta Hort. 1049:99-106, doi: 10.17660/ActaHortic.2014.1049.7.

Marcelis, L.F.M. 1996. Sink strength as a determinant of dry matter partitioning in the whole plant. J. Expt. Bot. 47:1281-1291, doi: 10.1093/ jxb/47.Special_Issue.1281.

Menzel, C.M. and L. Smith. 2014. The growth and productivity of 'Festival' strawberry plants growing in a subtropical environment. New Zeal. J. Crop Hort. 42:60-75, doi: 10.1080/ 01140671.2013 .850439 .

Muola, A. and J.A. Stenberg. 2018. Folivory has long-term effects on sexual but not on asexual reproduction in woodland strawberry. Ecol. Evol. 8:12250-12259, doi: 10.1002/ece3.4687.

Müller, D. and O. Leyser. 2011. Auxin, cytokinin and the control of shoot branching. Ann. Bot. 107:1203-1212, doi: 10.1093/aob/mcr069.

Narváez-Ortiz, W.A., J. H. Lieth, S.R. Grattan, A. Benavides-Mendoza, R.Y. Evans, P. PreciadoRangel, J.R. Valenzuela-García, and J.A. Gonzalez-Fuentes. 2018. Implications of physiological integration of stolon interconnected plants for salinity management in soilless strawberry production. Scientia Hort. 241:124-130, doi: 10.1016/j.scienta.2018.06.098

Nicola, O.S. 1998. Understanding root systems to improve seedling quality. HortTechnology 8:544-549, doi: 10.21273/HORTTECH.8.4.544.

Patrick, J.W. and K. Colyvas. 2014. Crop yield components -photoassimilate supply- or utilisation limited-organ development? Funct. Plant Biol. 41:893-913, doi: 10.1071/FP14048.

Paul, M.J. and C.H. Foyer. 2001. Sink regulation of photosynthesis. J. Expt. Bot. 52:1383-1400, doi: $10.1093 /$ jexbot $/ 52.360 .1383$.

Roiloa, S.R. and R. Retuerto. 2006. Physiological integration ameliorates effects of serpentine soils in the clonal herb Fragaria vesca. Physiol. Plant. 128:662-676, doi: 10.1111/j.13993054.2006.00790.x

Sato, S. and H. Mori. 2001. Control of outgrowth and dormancy in axillary buds. Plant Physiol. 127:1405-1413, doi: 10.1104/pp.010841.

Savini, G., V. Giorgi, E. Scarano, and D. Neri. 2008. Strawberry plant relationship through the stolon. Physiol. Plant. 134:421-429, doi: 10.1111/j.1399-3054.2008.01145.x.

Sønsteby, A. and O.M. Heide. 2007. Long-day control of flowering in everbearing strawberries. J. Hort. Sci. Biotechnol. 82:875-884, doi 10.1080/14620316.2007.11512321. 
Sugiyama, N., T. Iwama, Y. Inaba, T. Kurokura, and D. Neri. 2004. Varietal differences in the formation branch crowns in strawberry plants. HortScience 73:216-220, doi: 10.2503/ jjshs.73.216.

Takeda, F., S.C. Hokanson, and J.M. Enns. 2004. Influence of daughter plant weight and position on strawberry transplant production and field performance in annual plasticulture. HortScience
39:1592-1595, doi: 10.21273/HORTSCI.39.7. 1592.

Tenreira, T., M.J. Lange, T. Lange, C. Bres, M. Labadie, A. Monfort, M. Hernould, C. Rothan, and B. Dengoyes. 2017. A specific gibberellin 20-Oxidase dictates the floweringrunnering decision in diploid strawberry. Plant Cell 29:2168-2182, doi: 10.1105/ tpc.16.00949.
Turgeon, R. 1989. The sink-source transition in leaves. Annu. Rev. Plant Physiol. Plant Mol. Biol. 40:119-138, doi: 10.1146/annurev.pp.40. 060189.001003.

Xu, X. and R. Hérnandez. 2020. The effect of light intensity on vegetative propagation efficacy, growth, and morphology of "Albion" strawberry plants in a precision indoor propagation system. Appl. Sci. (Basel) 10, doi: 10.3390/app10031044. 